\title{
Characterization of different FAD-dependent glucose dehydrogenases for possible use in glucose-based biosensors and biofuel cells
}

\author{
Muhammad Nadeem Zafar • Najat Beden • \\ Dónal Leech • Christoph Sygmund • Roland Ludwig • \\ Lo Gorton
}

Received: 5 October 2011 /Revised: 6 December 2011 / Accepted: 10 December 2011 / Published online: 6 January 2012

(C) The Author(s) 2012. This article is published with open access at Springerlink.com

\begin{abstract}
In this study, different flavin adenine dinucleotide (FAD)-dependent glucose dehydrogenases (FADGDHs) were characterized electrochemically after "wiring" them with an osmium redox polymer $\left[\mathrm{Os}\left(4,4^{\prime} \text {-dimethyl-2,2'-bipyridine }\right)_{2}\right.$ $\left.(\mathrm{PVI})_{10} \mathrm{Cl}\right]^{+}$on graphite electrodes. One tested FADGDH was that recently discovered in Glomerella cingulata $(G c \mathrm{GDH})$, another was the recombinant form expressed in Pichia pastoris ( $r G c \mathrm{GDH})$, and the third was a commercially available glycosylated enzyme from Aspergillus sp. $(A s p \mathrm{GDH})$. The performance of the Os-polymer "wired" GDHs on graphite electrodes was tested with glucose as the substrate. Optimal operational conditions and analytical characteristics like sensitivity, linear ranges and current density of the different FADGDHs were determined. The performance of all three types of FADGDHs was studied at physiological conditions ( $\mathrm{pH}$ 7.4). The current densities measured at a $20 \mathrm{mM}$ glucose concentration were $494 \pm 17,370 \pm 24$, and $389 \pm 19 \mu \mathrm{A} \mathrm{cm}^{-2}$ for $G c \mathrm{GDH}, r G c \mathrm{GDH}$, and $A s p \mathrm{GDH}$,
\end{abstract}

M. N. Zafar $(\triangle) \cdot$ N. Beden $\cdot$ L. Gorton

Department of Biochemistry and Structural Biology,

Lund University,

P. O. Box 124, 22100 Lund, Sweden

e-mail: MNadeem.Zafar@biochemistry.lu.se

M. N. Zafar

e-mail: znadeempk@yahoo.com

D. Leech

School of Chemistry, National University of Ireland Galway,

University Road,

Galway, Ireland

C. Sygmund $\cdot$ R. Ludwig

Food Biotechnology Laboratory,

Department of Food Sciences and Technology,

BOKU-University of Natural Resources and Life Sciences Vienna,

Muthgasse 18,

1190 Wien, Austria respectively. The sensitivities towards glucose were 2.16, 1.90 , and $1.42 \mu \mathrm{A} \mathrm{mM}^{-1}$ for $G c \mathrm{GDH}, r G c \mathrm{GDH}$, and Asp GDH, respectively. Additionally, deglycosylated $r G c \mathrm{GDH}$ ( $\mathrm{dg} r G c \mathrm{GDH})$ was investigated to see whether the reduced glycosylation would have an effect, e.g., a higher current density, which was indeed found. GcGDH/Os-polymer modified electrodes were also used and investigated for their selectivity for a number of different sugars.

Keywords Glucose biosensor · FAD · Glucose dehydrogenase · Os-polymer - Deglycosylation · Biofuel cell

\section{Introduction}

Glucose monitoring systems that measure the blood glucose level of diabetic patients are a necessity for diabetes management. Amperometric biosensors have therefore gained much attention in the field of blood glucose monitoring and clinical analysis, but also food industry and environmental monitoring. A variety of different amperometric glucose biosensors has been developed and commercialized for the last two to three decades, but still a lot of effort is put into further development and improvement of their performance [1-5].

Glucose electro-oxidizing anodes are also of importance for glucose-based biofuel cells, which are proposed as in vivo power sources for pacemakers, micropumps, and so forth [6-18]. The key issues for a biofuel cell application are the establishment of new, robust bioelectrocatalytic systems, improvement of power output and stability and high cell performance in real samples [10, 19]. Among today's glucoseoxidizing enzymes, which are used as biocatalysts for biosensors or biofuel cell anodes, glucose oxidase (GOx) has been the most widely used redox enzyme due to its thermostability and high selectivity for glucose. 
In the early days of glucose biosensor development, the reaction catalyzed by GOx on, or close to, the electrode surface was followed through electrochemical monitoring of either the liberated $\mathrm{H}_{2} \mathrm{O}_{2}$, or the consumed $\mathrm{O}_{2}$. However, both reactions suffer from the applied, extreme potentials opening up the sensor system for interfering reactions $[20$, 21]. This problem was circumvented by the introduction of artificial redox mediators [1, 3, 5, 14, 22], using a lower potential range that favors a higher selectivity in biological fluids. With efficient artificial mediators available also other redox enzymes, e.g., glucose dehydrogenase, which are insensitive to oxygen, became interesting for biosensors and biofuel cells [20,21].

Two types of glucose dehydrogenases have been utilized for glucose-based biosensors and biofuel cells. The first is a quinoprotein glucose dehydrogenase having pyrroloquinoline quinone as bound cofactor (PQQGDH), which can use different electron acceptors as redox mediators except oxygen, and have an acceptable good electron transfer kinetics [4]. There are two kinds of PQQGDHs; one is intracellular and soluble and the other one is tightly bound to the outer surface of the membrane. Membrane bound PQQGDH has high glucose selectivity but requires suitable detergents for solubilization and purification [23], while soluble PQQGDH exhibits a low substrate specificity and lacks thermal stability [24, 25]. The other type is nicotinamide adenine dinucleotide (NAD) dependent glucose dehydrogenase that exhibits higher substrate specificity and stability than PQQGDH. There are, however, several disadvantages with sensor systems based on NADdependent dehydrogenases. The cofactor is not strongly bound to the enzyme and needs to be added, it is not longterm stable in either its oxidized form or in its reduced form and the electrochemistry suffers from very high overvoltages and side reactions causing electrode fouling [22]. Therefore, sensor systems based on such enzymes need either an NADH oxidizing enzyme such as NADH dehydrogenases (EC 1.6.99-diaphorase) or a $2 \mathrm{e}^{-}, 2 \mathrm{H}^{+}$acceptor, i.e., a quinoic type mediator, to be present in the system to be able to oxidize $\mathrm{NADH}$ to $\mathrm{NAD}^{+}$at a low potential [22].

In addition to the above-mentioned enzymes, thermostable FAD-dependent glucose dehydrogenases (FADGDH) have begun to gain attention in the field of bioelectrochemistry. Different thermostable FADGDHs have been reported [26-32]. FADGDH (EC 1.1.99.10, D-glucose: acceptor 1oxidoreductase) was first discovered in 1951 in Aspergillus oryzae [30] but remained a little investigated enzyme. Since the usage of FADGDH as electrode catalyst for glucose biosensors [26] and for biofuel cell anodes [33] was promoted, more attention was drawn to it and new members of this type of enzyme were identified from different fungal species [34-36]. However, very few reports have been published on FADGDH-based electrodes. The advantages of FADGDHs for glucose biosensors are high turnover rates and substrate selectivity, good stability, a lower redox potential than that of PQQGDHs and an oxidative half-reaction of the reduced FAD that is unaffected by molecular oxygen. Due to these properties FADGDHs are interesting candidates for the construction of oxygen insensitive amperometric glucose biosensors and glucose biofuel cell anodes. In this study, three FADGDHs were characterized with respect to biosensor and biofuel cell applications. The recently discovered enzyme from Glomerella cingulata (GcGDH) and the recombinantly in Pichia pastoris produced $G c \mathrm{GDH}(r G c \mathrm{GDH})$, were compared with the commercially available GDH from Aspergillus sp. (AspGDH). An Os-polymer $\left[\mathrm{Os}\left(4,4^{\prime} \text {-dimethyl-2,2'-bipyridine }\right)_{2}(\mathrm{PVI})_{10} \mathrm{Cl}\right]^{+}$, which was previously found to be optimal for $G c \mathrm{GDH}$ [37], was used in this study to "wire" the FADGDHs. Furthermore, the effect of the glycosylation in respect to the behavior on the electrode was also investigated using $r G c \mathrm{GDH}$ and its deglycosylated form ( $\operatorname{dg} r G c \mathrm{GDH})$ as an example.

\section{Materials and methods}

\section{Chemicals and materials}

The enzyme preparation of glucose dehydrogenase from $G$. cingulata $(G c \mathrm{GDH})$ with a molecular mass of $95-135 \mathrm{kDa}$ (different glycoforms) was a liquid preparation with a protein concentration of $7.4 \mathrm{mg} \mathrm{mL}^{-1}$ and a specific activity of $878 \mathrm{U}$ $\mathrm{mg}^{-1}$ and prepared according to [38]. Recombinantly, in $P$. pastoris, expressed $G c \mathrm{GDH}(r G c \mathrm{GDH})$ with a molecular mass of $88-131 \mathrm{kDa}$ (glycoforms) was a liquid preparation with a protein concentration of $15 \mathrm{mg} \mathrm{mL}^{-1}$, and a specific activity of $836 \mathrm{Umg}^{-1}$ and was prepared according to [39]. Deglycosylated, recombinantly expressed $\operatorname{dg} r G c \mathrm{GDH}$ with a molecular mass of $67 \mathrm{kDa}$ was a liquid preparation with a protein concentration of $15 \mathrm{mg} \mathrm{mL}^{-1}$ and a specific activity of $795 \mathrm{Umg}^{-1}$. For the deglycosylation, $r G c$ GDH was treated with Endo Hf (0.1 mg per mg $r G c \mathrm{GDH}$, New England Biolabs) and $\alpha$-mannosidase ( $0.1 \mathrm{mg}$ per $\mathrm{mg} r G c \mathrm{GDH}$, Sigma-Aldrich) and subsequent purification by size exclusion chromatography. Asp GDH from Aspergillus sp. (molecular mass $=97 \mathrm{kDa}$, volumetric activity $6,500 \mathrm{UmL}^{-1}$ ) was obtained as a powder and a kind gift by Genzyme, UK (www.genzymediagnostics.com). Osmium redox polymer $\left[\mathrm{Os}\left(4,4^{\prime} \text {-dimethyl-2,2'-bipyridine }\right)_{2}(\mathrm{P}\right.$ $\left.\mathrm{VI})_{10} \mathrm{Cl}\right]^{+}$, was synthesized as reported previously in [40].

Potassium phosphate dibasic was purchased from SigmaAldrich (Stockholm, Sweden). Poly(ethyleneglycol) (400) diglycidyl ether (PEGDGE) was purchased from Polysciences (Warrington, PA, USA). D(+)-Glucose, $\mathrm{D}(+)$-cellobiose, $\mathrm{D}(+)-$ lactose, D-gluconic acid, $\mathrm{D}(+)$-mannitol, $\mathrm{D}(+)$-mannose, 2deoxy-D-glucose, $\mathrm{D}(+)$-galactose, $\mathrm{D}(+)$-maltose, $\mathrm{D}(+)$-xylitol, $\mathrm{D}(-)$-fructose, fucose, $\mathrm{D}(+)$-trehalose, and $\mathrm{D}$-sorbitol were from Sigma-Aldrich (Stockholm, Sweden). D(+)-Xylose, rhamnose, and acetaminophen were from ICN Biomedicals, Inc. 
(Columbus, OH, USA). Arabinose was from Sigma (St Louis). $\mathrm{D}(+)$-Glucosamine and sucrose were from Chemicon (Malmö, Sweden). The water was purified in a Milli-Q water purification system (Millipore, Bedford, MA, USA). Standard solutions were prepared by dissolving appropriate amounts in the buffer used as carrier in the flow system (see below) and degassed before use to avoid air bubble formation in the flow system.

Electrode preparation and equipment

For the flow injection measurements, the electrodes were mounted into a flow-through amperometric cell of the wall jet type [41] containing a platinum wire counter electrode and an $\mathrm{Ag} \mid \mathrm{AgCl}_{0.1 \mathrm{M} \mathrm{KCl}}$ reference electrode (+288 mV vs. NHE). The potential of the working electrode vs. the reference electrode was kept at the required value using a three-electrode potentiostat (Zäta Elektronik, Höör, Sweden). The electrode response was registered with a recorder (BD 112, Kipp \& Zonen, Delft, The Netherlands). Samples were injected with an injector (Rheodyne, type 7125 LabPRO, Cotati, CA, USA) supplied with an injection loop of $50 \mu \mathrm{L}$. A $50 \mathrm{mM}$ potassium phosphate buffer solution at $\mathrm{pH} 7.4$ was used as the carrier in the flow system and pumped at a flow rate of $0.5 \mathrm{~mL} \mathrm{~min}{ }^{-1}$ (Minipuls 2, Gilson, Villier-le-Bel, France). Cyclic voltammetry experiments were performed with an Autolab PGSTAT 30 (Utrecht, The Netherlands) or an EG\&G potentiostat/galvanostat model 273 A (Princeton Applied Research, Oak Ridge, TN, USA) using modified graphite electrodes as working electrode, a saturated calomel reference electrode (SCE), and a platinum foil counter electrode. Argon was purged through the solutions for at least $15 \mathrm{~min}$ prior to the experiments. All the results presented below are referred to $\mathrm{Ag} \mid \mathrm{AgCl}_{0.1 \mathrm{M} \mathrm{KCl}}$ reference electrode.

Graphite rods (Ringsdorff Werke, Bonn, Germany) were prepared as described previously in $[42,43]$. The geometric surface area of the graphite rods is $0.071 \mathrm{~cm}^{2}$ and the roughness factor is approx. 5 [44]. The Os-polymer was dissolved in Milli-Q water at a concentration of $10 \mathrm{mg} \mathrm{mL}^{-1}$. One microliter of an enzyme solution with a protein activity of $6.5 \mathrm{U}_{\mu} \mathrm{L}^{-1}$ was spread evenly on the top of the polished electrode. After $5 \mathrm{~min}$, $2 \mu \mathrm{L}$ of Os-polymer solution $\left(10 \mathrm{mg} \mathrm{mL}^{-1}\right)$ followed by $1 \mu \mathrm{L}$ of freshly prepared PEGDGE solution $\left(10 \mathrm{mg} \mathrm{mL}^{-1}\right.$ in water) was placed on top of the first layer of the electrode. The electrodes were kept overnight at $4{ }^{\circ} \mathrm{C}$ under constant humidity for complete cross-linking [43, 45].

\section{Results and discussion}

Cyclic voltammetry of osmium redox polymer

The electrochemical behavior of the Os-polymer [Os $\left(4,4^{\prime}-\right.$ dimethyl-2,2'-bipyridine $\left.)_{2}(\mathrm{PVI})_{10} \mathrm{Cl}\right]^{+}$was characterized using cyclic voltammetry in the presence and absence of GcGDH in $50 \mathrm{mM}$ potassium phosphate buffer at $\mathrm{pH} 7.4$ without substrate. The structure of this Os-polymer is shown in Fig. 1a. The polymer was selected previously out of six different Os-polymers covering a broad potential range, because it gave the highest current density [37]. The formal redox potentials $\left(E^{\circ \prime}\right)$ of the polymer was determined to be $21 \mathrm{mV}$ vs. $\mathrm{Ag} \mid \mathrm{AgCl}_{0.1} \mathrm{M} \mathrm{KCl}$ for $\left[\mathrm{Os}\left(4,4^{\prime}\right.\right.$-dimethyl-2,2'bipyridine $\left.)_{2}(\mathrm{PVI})_{10} \mathrm{Cl}\right]^{+}$. This value agrees well with the literature values [40] and with our previous results [14]. The rather low $E^{\circ \prime}$ value minimizes the effects of interfering components by preventing their direct electrochemically oxidation at the electrode surface at high potential. Due to these preliminary results and the fact that the polymer has been already used to successfully "wire" different redox enzymes in biosensors and biofuel cells [14, 46, 47], it was selected for this study. The possibility to successfully "wire"
Fig. 1 a Structure of the Ospolymer $\left[\mathrm{Os}\left(4,4^{\prime}\right.\right.$-dimethyl-2, $2^{\prime}$-bipyridine $\left.)_{2}(\mathrm{PVI})_{10} \mathrm{Cl}\right]^{+}$. b Cyclic voltammogram of the Os-polymer on graphite electrode: (solid line) without enzyme, (broken line) with cross-linked $G c$ GDH. Experiments were performed in $50 \mathrm{mM}$ phosphate buffer at $\mathrm{pH} 7.4$ and the scan rate was $10 \mathrm{mV} \mathrm{s}^{-1}$
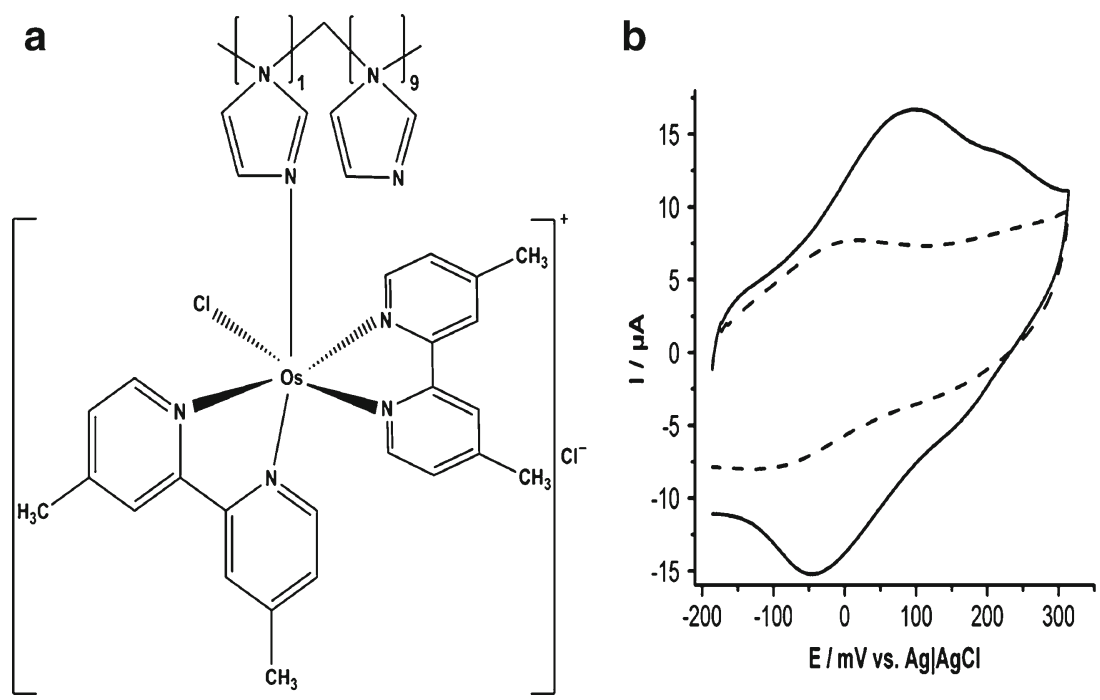
the other FADGDHs to graphite rod electrodes was therefore anticipated [43]. The mechanism of interaction and electron transfer between enzymes and Os-polymers is well described in the following reports $[45,48-50]$. The FADGDHs belong to the same structural family of GMC oxidoreductases (glucose-methanol-choline oxidoreductase) as GOx [51]. Similar to GOx, the FADGDHs oxidize glucose at the $\mathrm{C} 1$ position and only the $\beta$-form is oxidized and $2 \mathrm{e}^{-} / 2 \mathrm{H}^{+}$are transferred from glucose to the bound FAD, Reaction 1. The electron transfer occurs between FADGDHs and Os-polymers through the following reactions.

$$
\begin{aligned}
& \beta-\mathrm{D}-\text { glucose }+\mathrm{GDH}_{\mathrm{FAD}} \\
& \rightarrow \text { gluconolactone }+\mathrm{GDH}_{\mathrm{FADH}_{2}}
\end{aligned}
$$

Then the Os-complexes attached to the polymer, acting as $1 \mathrm{e}^{-}$non- $\mathrm{H}^{+}$acceptors, reoxidize the reduced enzyme. The sum of the reoxidation reaction is given by Reaction 2 .

$$
\mathrm{GDH}_{\mathrm{FADH}_{2}}+2 \mathrm{Os}^{3+} \rightarrow \mathrm{GDH}_{\mathrm{FAD}}+2 \mathrm{Os}^{2+}+2 \mathrm{H}^{+}
$$

Finally, the reduced Os-complexes are reoxidized by the electrode having an applied potential $\left(E_{\text {app }}\right)$ higher than the $E^{\circ \prime}$ of the redox polymer, reaction (3).

$\mathrm{Os}^{2+} \stackrel{E_{\text {opp }}>E^{\circ \prime}}{\longrightarrow} \mathrm{Os}^{3+}+1 \mathrm{e}^{-}$

In an ideal setup, the enzyme is perfectly electrically connected to the electrode and the measured current (the analytical response signal) represents the actual turnover rate of the enzyme [43]. The turnover rate and likewise the current increase linearly with the diffusional flux of the substrate and with the substrate concentration until the maximum turnover rate of the enzyme is reached [43].

To observe any interaction between the Os-polymer and FADGDHs, cyclic voltammograms (CVs) were recorded for electrodes made with Os-polymer in the presence and absence of $G c \mathrm{GDH}$ in $50 \mathrm{mM}$ phosphate buffer at $\mathrm{pH} 7.4$ without substrate. The PEGDGE cross-linker was used for crosslinking of both types of electrodes. The Os-polymer exhibited a single redox couple as shown in the CVs in Fig. 1b. When coimmobilized with GcGDH (Fig. 1b), the wave was slightly shifted into a more negative potential region reflecting the electrostatic interaction between redox polymer and enzyme. This effect was also seen in previous work [14, 43, 52].

For the work with the different FADGDH-modified electrodes in the flow system, the proper working potential was chosen according to the CVs shown in Fig. 1b. The amperometric measurements were thus performed at $+175 \mathrm{mV}$ in all experiments reported below, so that there should be sufficient electrochemical driving force to keep the Os-polymer completely in its oxidized form.
Effect of $\mathrm{pH}$

The $\mathrm{pH}$ dependence of the FADGDH/Os-polymer modified graphite electrodes was tested in the electrochemical flowthrough cell by varying the $\mathrm{pH}$ of the phosphate carrier buffer solution between 6.0 and 8.5 . Figure $2 \mathrm{a}$ shows the

a

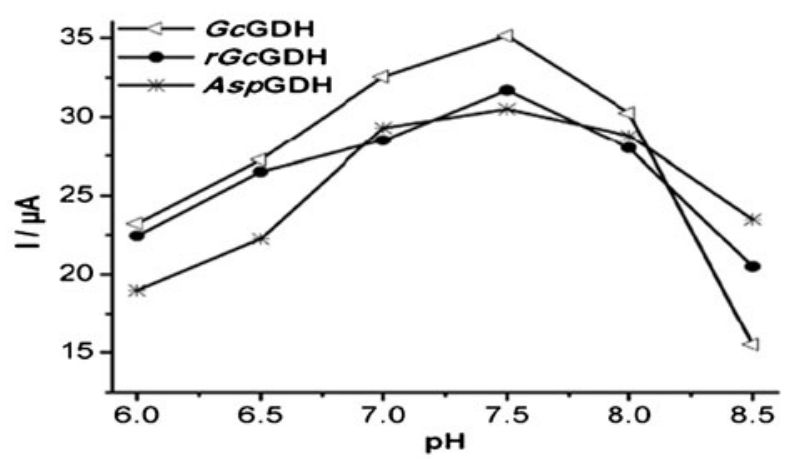

b

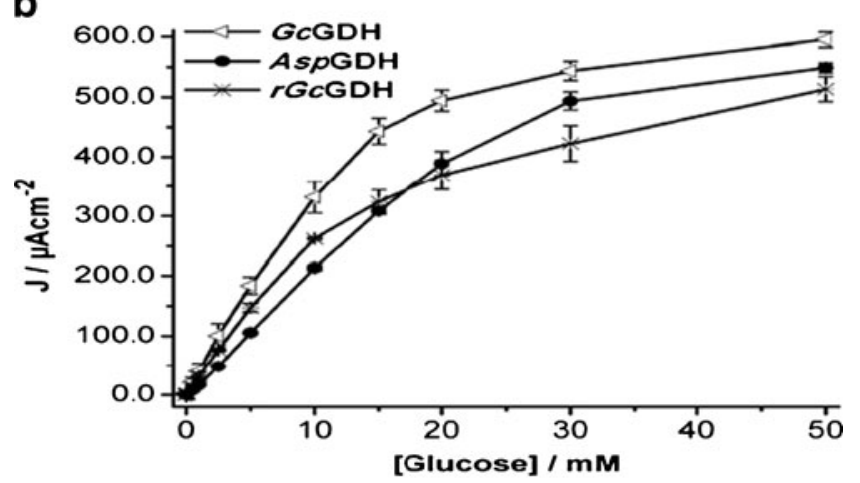

C

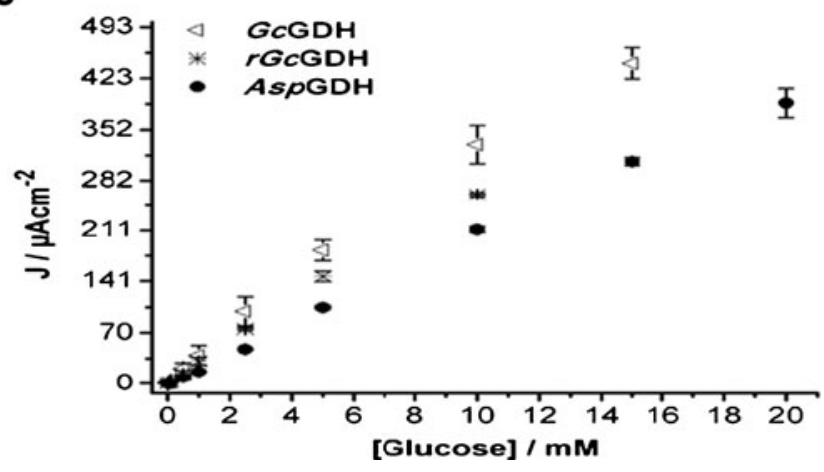

Fig. 2 a Effect of $\mathrm{pH}$ on the response of the $G c \mathrm{GDH} / \mathrm{Os}-$ polymer, $r G c \mathrm{GDH} / \mathrm{Os}-$ polymer and AspGDH/Os-polymer modified graphite electrodes. Experiments were performed in $50 \mathrm{mM}$ phosphate buffer containing $20 \mathrm{mM}$ glucose solution. The flow rate was $0.5 \mathrm{~mL} \mathrm{~min}{ }^{-1}$ and the working potential was set to +175 vs. $A g \mid \mathrm{AgCl}_{0.1 \mathrm{M} \mathrm{KCl}}$. b Calibration graphs (current densities) of $G c \mathrm{GDH} / \mathrm{Os}-$ polymer, $r G c \mathrm{GDH} / \mathrm{Os}$-polymer and $A s p \mathrm{GDH} / \mathrm{Os}$-polymer modified graphite electrodes. Experiments were performed in $50 \mathrm{mM}$ phosphate buffer at $\mathrm{pH} 7.4$ containing various glucose concentrations. The flow rate was $0.5 \mathrm{~mL} \mathrm{~min}{ }^{-1}$ and the working potential was set to $+175 \mathrm{mV}$ vs. $\mathrm{Ag}$ $\mathrm{AgCl}_{0.1 \mathrm{M} \mathrm{KCl}}$. c Linear range of the glucose calibration curves of $G c \mathrm{GDH} /$ Os-polymer, $r G c \mathrm{GDH} / \mathrm{Os}-$ polymer and $A s p \mathrm{GDH} / \mathrm{Os}$-polymer modified graphite 
results obtained by injecting samples of $20 \mathrm{mM}$ glucose. Compared to the other two GDHs, AspGDH exhibits a slightly broader $\mathrm{pH}$ profile between $\mathrm{pH} 7.0-8.0$ and therefore also less sensitive to $\mathrm{pH}$ drifts of an electrode, but for all three measured GDHs the $\mathrm{pH}$ optimum was found to be $\mathrm{pH}$ 7.5. At this $\mathrm{pH}$, which is close to the $\mathrm{pH}$ of physiological conditions, GcGDH $(35.1 \mu \mathrm{A})$ showed the highest activity, as revealed by the response current, followed by $r G c \mathrm{GDH}$ $(31.7 \mu \mathrm{A})$, and $A s p \mathrm{GDH}(30.5 \mu \mathrm{A})$.

\section{Analytical characteristics}

Calibration graphs for glucose using three modified graphite electrodes based on $G c \mathrm{GDH}, r G c \mathrm{GDH}$, and $A s p \mathrm{GDH}$ (in equal amounts in terms of activities) along with the Os-polymer are presented in Fig. 2b and the analytical characteristics are summarized in Table 1. The values of the apparent MichaelisMenten constants $\left(K_{\mathrm{M}}^{\mathrm{app}}\right)$ and maximum current $\left(I_{\max }\right)$ were calculated by fitting the data to the Michaelis-Menten equation using least square regression (Table 1). The value of $K_{\mathrm{M}}^{\mathrm{app}}$ is a reflection of both the affinity of the enzyme for the substrate and, as the enzyme is immobilized in the three-dimensional hydrogel on the electrode surface, it also reflects any masstransfer resistance of the substrate in the polymer. A low $K_{\mathrm{M}}^{\text {app }}$ indicates thus either a high affinity of the enzyme for the substrate or a fast diffusion through the polymer, while a high $K_{\mathrm{M}}^{\mathrm{app}}$ indicates a low affinity but also a high mass-transfer resistance [53]. In this study, the polymer is the same and therefore assumed to have a similar mass-transfer resistance for all tested enzymes. The lowest $K_{\mathrm{M}}^{\mathrm{app}}$ value of $13.6 \mathrm{mM}$ and therefore the highest affinity towards glucose was obtained for the $G c \mathrm{GDH}$-based biosensor, followed by the $r G c \mathrm{GDH}$-based biosensor with a $K_{\mathrm{M}}^{\mathrm{app}}$ value of $17.4 \mathrm{mM}$ and the $A s p \mathrm{GDH}$ based biosensor with a $K_{\mathrm{M}}^{\text {app }}$ value of $23.4 \mathrm{mM}$. All three tested FADGDHs exhibited high $I_{\max }$ values of between 50 and $60 \mu \mathrm{A}$. The catalytic current values divided by the geometric surface area of the electrode result in the following current densities of $494 \pm 17,370 \pm 24$, and $389 \pm 19 \mu \mathrm{A} \mathrm{cm}^{-2}$ for the GcGDH-, $r G c \mathrm{GDH}-$, and $A s p$ GDH-based biosensors, respectively, for $20 \mathrm{mM}$ glucose (and using an injection volume of
$50 \mu \mathrm{L}$ and a flow rate of $0.5 \mathrm{~mL} \mathrm{~min}{ }^{-1}$ ). In Fig. $2 b$, the calibration curves for $G c \mathrm{GDH}$ and $r G c \mathrm{GDH}$ have a similar shape, which demonstrate that the catalytic constants of the two enzymes are almost similar. The catalytic constants in solution $k_{\text {cat }}$ and $k_{\text {cat }} / K_{\mathrm{M}}$ for $G c \mathrm{GDH}$ and $r G c \mathrm{GDH}$ are $380 \pm 6,418 \pm$ $4 \mathrm{~s}^{-1}$ and $2.0 \times 10^{4}, 2.5 \times 10^{4} \mathrm{M}^{-1} \mathrm{~s}^{-1}$ respectively [38]. Only the current density and thus the $I_{\max }$ for the $r G c \mathrm{GDH}$ electrode is lower, which might be due to a lower enzyme loading on the electrode. The different calibration curve for Asp GDH suggests a higher $\mathrm{K}_{\mathrm{M}}^{\mathrm{app}}$ for glucose and also demonstrates different catalytic constants.

Figure $2 \mathrm{c}$ shows the linear part of the calibration curves obtained for glucose for all three tested biosensors. At higher concentrations, the calibration curves showed a deviation from linearity due to substrate saturation. The sensitivity, linear range and detection limits for glucose were calculated from the calibration curves for the biosensors and are presented in Table 1 . The highest sensitivity for glucose $\left(2.16 \mu \mathrm{A} \mathrm{mM}^{-1}\right)$ was obtained with the biosensor based on $G c \mathrm{GDH}$. The biosensors based on $r G c \mathrm{GDH}$ and $A s p \mathrm{GDH}$ showed slightly lower sensitivities for glucose: 1.90 and $1.42 \mu \mathrm{A} \mathrm{mM}{ }^{-1}$ respectively. The linear range for biosensors based on $G c \mathrm{GDH}$ and Asp GDH were between $0.005-18 \mathrm{mM}$ glucose and $0.005-20 \mathrm{mM}$ glucose, respectively. The $r G c$ GDH-based biosensor showed a smaller linear range of $0.005-12 \mathrm{mM}$ glucose. The detection limit for glucose $(3.4 \mu \mathrm{M})$ was almost identical for all three biosensors. In conclusion, $G c \mathrm{GDH}$ showed better sensitivity and lower limit of detection and comparable linear range with already published reports on FADGDHs [27, 28].

The selectivity of the $G c \mathrm{GDH} / \mathrm{Os}$-polymer-based system was tested with different substrates. Sugars such as galactose, fructose, mannose and maltose as well as compounds like ascorbic acid, uric acid and acetaminophen, which might be present in blood samples were used to identify possible crossreactivities [54]. These interfering substances normally appear in very low concentrations in human blood (e.g., ascorbic acid, uric acid, and acetaminophen less than $1 \mathrm{mM}$ ) [55]. Nien et al. in his study showed that the current responses of these interferences such as ascorbic acid, uric acid and acetaminophen were about $\sim 0 \%, \sim 0 \%$, and $3 \%$, respectively, based on

Table 1 Comparison of different parameters for GcGDH/Os-polymer, AspGDH/Os-polymer, $r G c \mathrm{GDH} / \mathrm{Os}$-polymer, and dgrGcGDH/Os-polymer modified electrodes

\begin{tabular}{lcccr}
\hline Enzymes & $K_{\mathrm{M}}^{\mathrm{app}}(\mathrm{mM})$ & $I_{\max }(\mu \mathrm{A})$ & Sensitivities $\left(\mu \mathrm{A} \mathrm{mM}{ }^{-1}\right)$ & Linear ranges $(\mathrm{mM})$ \\
\hline$G c \mathrm{GDH}$ & $13.6 \pm 1.5$ & $56.0 \pm 2.4$ & $2.16 \pm 0.07$ & $0.005-18$ \\
Asp GDH & $23.4 \pm 4.3$ & $58.3 \pm 2.9$ & $1.42 \pm 0.10$ & $0.005-20$ \\
$r G c \mathrm{GDH}$ & $17.4 \pm 0.9$ & $48.8 \pm 1.2$ & $1.90 \pm 0.05$ & $0.005-12$ \\
$\operatorname{dg} r G c \mathrm{GDH}$ & $13.9 \pm 3.1$ & $51.5 \pm 2.6$ & $2.15 \pm 0.13$ & 0.991 \\
\hline
\end{tabular}

Experiments were performed in a $50 \mathrm{mM}$ phosphate buffer at $\mathrm{pH} 7.4$ containing various glucose concentrations. The flow rate was $0.5 \mathrm{~mL}^{-1}$ and the applied potential was set to $+175 \mathrm{mV}$ vs. $\mathrm{Ag} \mid \mathrm{AgCl}_{0.1 \mathrm{M} \mathrm{KCl}}$ 
the sensing current of $6.0 \mathrm{mM}$ glucose as $100 \%$ [56]. Nineteen such sugars were tested with GcGDH/Os-polymer-based modified electrodes using a sugar concentration of $20 \mathrm{mM}$. The results obtained are shown in Table 2. The highest relative activities compared to glucose were measured for 2-deoxy-Dglucose $(37.2 \%)$ and xylose $(22.7 \%)$. Xylose was already identified as the second best substrate in homogeneous solution (glucose, $K_{\mathrm{M}}=19 \mathrm{mM}, k_{\text {cat }}=380 \mathrm{~s}^{-1}$; xylose, $K_{\mathrm{M}}=$ $24 \mathrm{mM}, k_{\mathrm{cat}}=60 \mathrm{~s}^{-1}$ ) [38]. The high reactivity with 2-deoxyD-glucose shows that the modification at C-2 only moderately influenced the binding or the oxidation of glucose at C-1. For other substrates including galactose $(0.56 \%)$, mannose $(0.45 \%)$, and maltose $(0.29 \%)$, which can be present in blood samples, the relative activity varied between $0.1 \%$ and $3 \%$ (Table 2). Towards lactose, gluconic acid, mannitol, rhamnose, sorbitol, and fructose, GcGDH showed no detectable activity. An almost similar response profile to all these compounds was also observed for $A s p \mathrm{GDH}$-based system (results not shown). One can therefore conclude that these FADGDHs have at least equal selectivity for glucose compared with that of GOx and much better than PQQGDH, which is a critical parameter for use in diagnostics. Of the investigated, electrochemically active compounds only acetaminophen gave a strong response $(28.9 \%)$ at the applied potential but

Table 2 Substrate specificity of $G c \mathrm{GDH} / \mathrm{Os}$-polymer modified electrode using $20 \mathrm{mM}$ solution of each sugar

\begin{tabular}{lc}
\hline Substrate $(20 \mathrm{mM})$ & \% of Glucose activity \\
\hline Glucose & 100 \\
2-Deoxy-D-glucose & 37.2 \\
Xylose & 22.7 \\
Glucosamine & 3.00 \\
Cellobiose & 1.83 \\
Lactose & 0 \\
Gluconic acid & 0 \\
Mannose & 0.45 \\
Mannitol & 0 \\
Sorbitol & 0 \\
Galactose & 0.56 \\
Sucrose & 0.12 \\
Maltose & 0.29 \\
Arabinose & 0.52 \\
Xylitol & 0.16 \\
Rhamnose & 0 \\
Fucose & 0.26 \\
Trehalose & 0.18 \\
Fructose & 0 \\
\hline
\end{tabular}

Experiments were performed in a $50 \mathrm{mM}$ phosphate buffer at $\mathrm{pH}$ 7.4. The flow rate was $0.5 \mathrm{~mL} \mathrm{~min}^{-1}$ and the applied potential was set to $+175 \mathrm{mV}$ vs. $\mathrm{Ag} \mid \mathrm{AgCl}_{0.1 \mathrm{M} \mathrm{KCl}}$ acetaminophen is not a substrate of GDH. It might get reduced as an electron acceptor and most of its activity might be from direct oxidation at the electrode at this applied potential [56].

Stability tests

The operational stability is one of the key parameters of a biosensor. The long-term stability is not only beneficial to biosensor transport and storage but also helps to decrease the per measurement costs [55]. The operational stabilities of the $G c \mathrm{GDH} / \mathrm{Os}$-polymer and the $A s p \mathrm{GDH} / \mathrm{Os}$-polymer
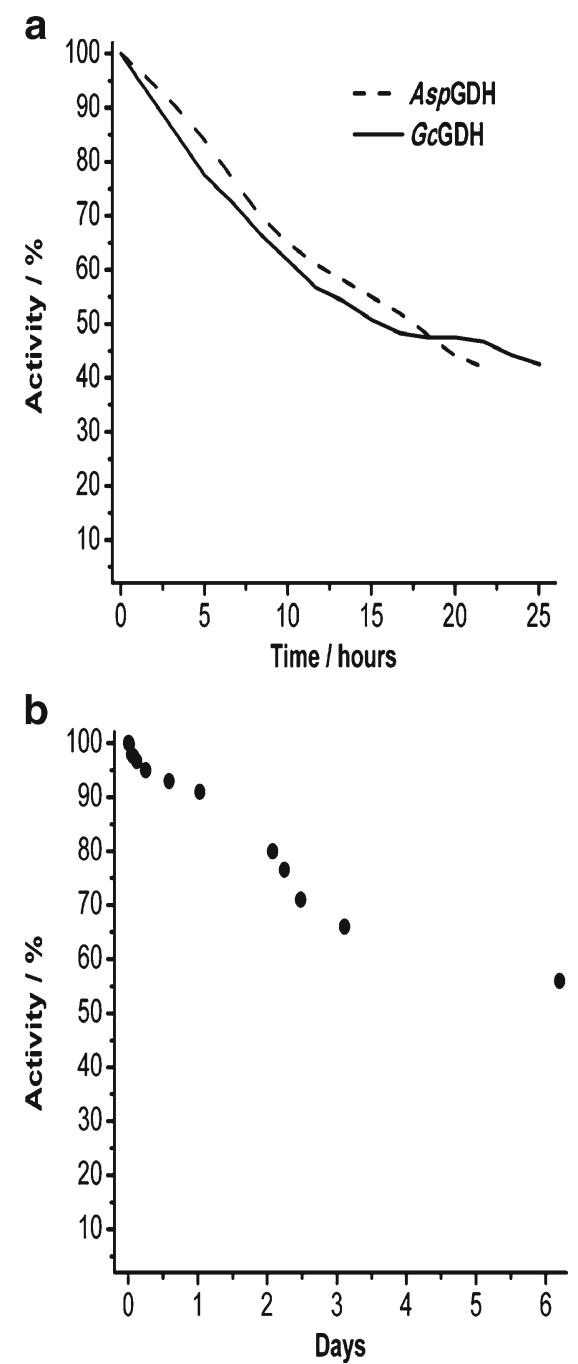

Fig. 3 Stability tests: a Variation of the response current for glucose with time for $G c \mathrm{GDH} / \mathrm{Os}$-polymer and AspGDH/Os-polymer modified electrodes in a constant flow of $5 \mathrm{mM}$ glucose solution throughout the duration of test up to $25 \mathrm{~h}$. Experiments were performed in $50 \mathrm{mM}$ phosphate buffer at $\mathrm{pH} 7.4$. The flow rate was $0.5 \mathrm{~mL} \mathrm{~min}^{-1}$ and the working potential was set to $+175 \mathrm{mV}$ vs. $\mathrm{Ag} \mid \mathrm{AgCl}_{0.1 \mathrm{M} \mathrm{KCl}}$. b Variation of the response current with time for $G c \mathrm{GDH} / \mathrm{Os}$-polymer modified electrode with consecutive injections of $5 \mathrm{mM}$ glucose as substrate for 6 days. Experiments were performed in $50 \mathrm{mM}$ phosphate buffer at $\mathrm{pH}$ 7.4. The flow rate was $0.5 \mathrm{~mL} \mathrm{~min}^{-1}$ and the applied potential was set to $+175 \mathrm{mV}$ vs. $\mathrm{Ag} \mid \mathrm{AgCl}_{0.1 \mathrm{M} \mathrm{KCl}}$ 
modified electrodes were investigated using a constant flow of a $5 \mathrm{mM}$ glucose solution throughout the duration of the test. Figure 3a shows the results of these stability tests performed for $25 \mathrm{~h}$. It should be noted that there was a slow decrease in the current response of both modified electrodes in the first $15 \mathrm{~h}$, which further decreased for the $A s p \mathrm{GDH} / \mathrm{Os}$-polymer-based electrode, but less strongly for the $G c \mathrm{GDH} / \mathrm{Os}$-polymer-based electrode. After $25 \mathrm{~h}$ with a constant flow of $5 \mathrm{mM}$ glucose, both modified electrodes kept almost $40 \%$ of their initial response to glucose.

Another stability test for the $G c \mathrm{GDH} / \mathrm{Os}$-polymer-based electrode consisted of consecutive measurements of its response to $5 \mathrm{mM}$ glucose. Figure $3 \mathrm{~b}$ shows the results of the operational stability test of $G c \mathrm{GDH} / \mathrm{Os}$-polymer modified electrode under storage conditions $(50 \mathrm{mM}$ phosphate buffer, $\mathrm{pH} 7.4,4{ }^{\circ} \mathrm{C}$ ). For this experiment, $50 \mu \mathrm{L}$ of a $5 \mathrm{mM}$ glucose solution was injected into the electrochemical cell for 6 days. It was observed that the biosensor kept more than $90 \%$ of its initial activity after the first day. One can see a slow and linear decrease in the response of the modified electrode during the first day of experiments and then a sudden break down after the second day. After 6 days, the current response was $56 \%$ of its initial response. As a conclusion, it can be pointed out that by simple adsorption of the enzymes in combination with electrostatic binding and covalent cross-linking to the Os-polymer on the graphite surface, one can obtain a modified electrode, which has a good and comparable stability with previously reported stabilities of modified electrodes using Os-polymers [28, 46, 47, 50] and can be operational for several days.

\section{Effect of deglycosylation}

To study the effect of deglycosylation on the sensor performance, equal amounts in terms of activities of $r G c \mathrm{GDH}$ and $\operatorname{dg} r G c \mathrm{GDH}$ were immobilized on graphite electrodes with the same Os-polymer loading and cross-linked using a $10 \mathrm{mg} \mathrm{mL}^{-1}$ of PEGDGE solution. The calibration curves for the enzyme modified electrodes using glucose as substrate are compared in Fig. 4. The results show that there is an increase in current density with the smaller $(68 \mathrm{kDa})$ $\mathrm{dg} r G c \mathrm{GDH}$. The current densities were $370 \pm 24$ and $520 \pm$ $20 \mu \mathrm{A} \mathrm{cm} ~^{-2}$ for $r G c \mathrm{GDH}$ and $\mathrm{dg} r G c \mathrm{GDH}$ respectively. With the deglycosylation of the enzyme the packing in the polymer or the "wiring" by the Os-complexes was improved and an increase in the current density and also in the linear response range was also observed. The linear range was between 0.005 and $12 \mathrm{mM}$ glucose for $r G c \mathrm{GDH}$, which was extended up to $16 \mathrm{mM}$ glucose for $\operatorname{dg} r G c \mathrm{GDH}$. The $K_{\mathrm{M}}^{\mathrm{app}}$ value for $\operatorname{dg} r G c \mathrm{GDH}$ was also lower than that of $r G c$ GDH (Table 1). The increase in the current density and improvement in the linear range after deglycosylation of the

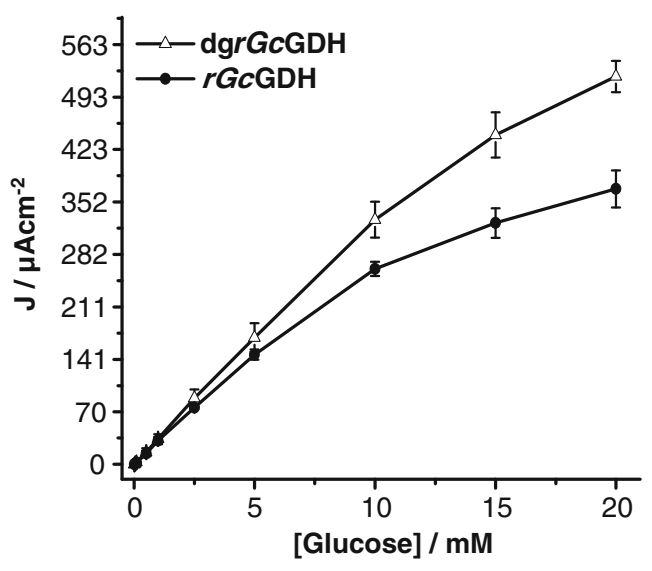

Fig. 4 Comparison of glycosylated $r G c \mathrm{GDH} / \mathrm{Os}-$ polymer and deglycosylated $\operatorname{dg} r G c \mathrm{GDH} / \mathrm{Os}$-polymer modified graphite electrodes. Experiments were performed in $50 \mathrm{mM}$ phosphate buffer at $\mathrm{pH} 7.4$ containing various glucose concentrations. The flow rate was $0.5 \mathrm{~mL} \mathrm{~min}^{-1}$ and the applied potential was set to $+175 \mathrm{mV}$ vs. $\mathrm{Ag}$ $\mathrm{AgCl}_{0.1 \mathrm{M} \mathrm{KCl}}$

enzyme might be due to a more efficient electron transfer between the bound $\mathrm{FADH}_{2}$ of $\mathrm{dg} r \mathrm{Gc} \mathrm{GDH}$ and the Os-polymer, probably by reduced steric hindrance. Additionally, it can be attributed to a higher Os-polymer concentration around the deglycosylated, smaller enzyme in the $\operatorname{dg} r G c \mathrm{GDH}$ electrode due to the smaller size and by an increased formation of electrostatic interactions between the enzyme and the Os-polymer [57, 58].

\section{Conclusion}

The investigated FADGDHs/Os-polymer-based electrodes show a high current density, a high sensitivity and a broad linear range towards glucose. The high selectivity of all enzymes towards glucose and the high turnover rates of this substrate suggests the application of these FADGDHs/Ospolymer-based systems for either glucose determination or as bioanodes in glucose biofuel cells. The enzyme/Os-polymer modified electrodes showed a good and comparable stability. The higher current density obtained with deglycosylated $G c \mathrm{GDH}$ modified electrodes suggests that the downsizing of the enzyme by deglycosylation is a promising way to enhance the electric contact between the enzyme and the electrode, which leads to the improvement of the electron transfer and thus the current density.

Acknowledgments The authors thank the following agencies for the financial support: The Higher Education Commission of Pakistan, The Swedish Research Council (VR, projects 621-2007-4124 and 20105031), a Science Foundation Ireland Charles Parsons Energy Research Award, and The European Commission (project "3D-nanobiodevice" NMP4-SL-2009-229255). The supply of the Aspergillus sp. GDH by Genzyme Diagnostics is gratefully acknowledged. 
Open Access This article is distributed under the terms of the Creative Commons Attribution Noncommercial License which permits any noncommercial use, distribution, and reproduction in any medium, provided the original author(s) and source are credited.

\section{References}

1. Cass AEG, Davis G, Francis GD, Hill HAO, Aston WJ, Higgins IJ, Plotkin EV, Scott LDL, Turner APF (1984) Ferrocene-mediated enzyme electrode for amperometric determination of glucose. Anal Chem 56(4):667-671

2. Ikeda T, Katash I, Kamei M, Senda M (1984) Electrocatalysis with a glucose-oxidase-immobilized graphite electrode. Agric Biol Chem 48(8):1969-1976

3. Kawaguchi M, Yoshioka T, Nankai S (1990) Disposable glucose sensor employing potassium ferricyanide as a mediator. Denki Kagaku 12:1119-1124

4. D'Costa EJ, Higgins IJ, Turner APF (1986) Quinoprotein glucose dehydrogenase and its application in an amperometric glucose sensor. Biosensors 2(2):71-87

5. Gregg BA, Heller A (1990) Cross-linked redox gels containing glucose oxidase for amperometric biosensor applications. Anal Chem 62(3):258-263

6. Barton SC, Gallaway J, Atanassov P (2004) Enzymatic biofuel cells for implantable and microscale devices. Chem Rev 104 (10):4867-4886

7. Bullen RA, Arnot TC, Lakeman JB, Walsh FC (2006) Biofuel cells and their development. Biosens Bioelectron 21(11):20152045

8. Kim J, Jia H, Wang P (2006) Challenges in biocatalysis for enzyme-based biofuel cells. Biotechnol Adv 24(3):296-308

9. Davis F, Higson SPJ (2007) Biofuel cells-recent advances and applications. Biosens Bioelectron 22(7):1224-1235

10. Heller A (2004) Miniature biofuel cells. Phys Chem Chem Phys 6 (2):209-216

11. Tasca F, Gorton L, Harreither W, Haltrich D, Ludwig R, Nöll G (2008) Highly efficient and versatile anodes for biofuel cells based on cellobiose dehydrogenase from Myriococcum thermophilum. J Phys Chem C 112(35):13668-13673

12. Coman V, Vaz-Dominguez C, Ludwig R, Harreither W, Haltrich D, De Lacey AL, Ruzgas T, Gorton L, Shleev S (2008) A membrane-, mediator-, cofactor-less glucose/oxygen biofuel cell. Phys Chem Chem Phys 10(40):6093-6096

13. Coman V, Ludwig R, Harreither W, Haltrich D, Gorton L, Ruzgas T, Shleev S (2010) A direct electron transfer-based glucose/oxygen biofuel cell operating in human serum. Fuel Cells (Weinheim, Germany) 10(1):9-16

14. Zafar MN, Tasca F, Boland S, Kujawa M, Patel I, Peterbauer CK, Leech D, Gorton L (2010) Wiring of pyranose dehydrogenase with osmium polymers of different redox potentials. Bioelectrochemistry 80(1):38-42

15. Tasca F, Harreither W, Ludwig R, Gooding JJ, Gorton L (2011) Cellobiose dehydrogenase aryl diazonium modified single walled carbon nanotubes: Enhanced direct electron transfer through a positively charged surface. Anal Chem 83(8):3042-3049

16. Zafar MN, Tasca F, Gorton L, Patridge EV, Ferry JG, Noll G (2009) Tryptophan repressor-binding proteins from Escherichia coli and Archaeoglobus fulgidus as new catalysts for 1,4-dihydronicotinamide adenine dinucleotide-dependent amperometric biosensors and biofuel cells. Anal Chem 81(10):4082-4088

17. Tasca F, Gorton L, Kujawa M, Patel I, Harreither W, Peterbauer CK, Ludwig R, Nöll G (2010) Increasing the coulombic efficiency of glucose biofuel cell anodes by combination of redox enzymes. Biosens Bioelectron 25(7):1710-1716
18. Ivanov I, Vidaković-Koch T, Sundmacher K (2010) Recent advances in enzymatic fuel cells: experiments and modeling. Energies 3 (4):803-846

19. Mano N, Mao F, Heller A (2003) Characteristics of a miniature compartment-less glucose- $\mathrm{O}_{2}$ biofuel cell and its operation in a living plant. J Am Chem Soc 125(21):6588-6594

20. Wilson R, Turner APF (1992) Glucose oxidase: an ideal enzyme. Biosens Bioelectron 7(3):165-185

21. Tang ZP, Louie RF, Lee JH, Lee DM, Miller EE, Kost GJ (2001) Oxygen effects on glucose meter measurements with glucose dehydrogenase and oxidase-based test strips for point-of-care testing. Crit Care Med 29(5):1062-1070

22. Gorton L, Domínguez E (2002) Electrocatalytic oxidation of NAD (P)H at mediator-modified electrodes. Rev Mol Biotechnol 82 (4):371-392

23. Matsushita K, Ohno Y, Shinagawa E, Adachi O, Ameyama M (1980) Membrane-bound D-glucose dehydrogenase from Pseudomonas sp.: solubilization, purification and characterization. Agric Biol Chem 44(7):1505-1512

24. Igarashi S, Hirokawa T, Sode K (2004) Engineering PQQ glucose dehydrogenase with improved substrate specificity: Site-directed mutagenesis studies on the active center of PQQ glucose dehydrogenase. Biomol Engineer 21(2):81-89

25. Igarashi S, Sode K (2003) Stabilization of quaternary structure of water-soluble quinoprotein glucose dehydrogenase. Mol Biotechnol 24(2):97-103

26. Sode K, Tsugawa W, Yamazaki T, Watanabe M, Ogasawara N, Tanaka M (1996) A novel thermostable glucose dehydrogenase varying temperature properties by altering its quaternary structures. Enzyme Microb Technol 19(2):82-85

27. Tsujimura S, Kojima S, Kano K, Ikeda T, Sato M, Sanada H, Omura H (2006) Novel FAD-dependent glucose dehydrogenase for a dioxygen-insensitive glucose biosensor. Biosci Biotechnol Biochem 70(3):654-659

28. Yamazaki T, Okuda-Shimazaki J, Sakata C, Tsuya T, Sode K (2008) Construction and characterization of direct electron transfer-type continuous glucose monitoring system employing thermostable glucose dehydrogenase complex. Anal Lett 41 (13):2363-2372

29. Desriani HT, Yamazakib T, Tsugawaa W, Sode K (2010) Enzyme fuel cell for cellulolytic sugar conversion employing FAD glucose dehydrogenase and carbon cloth electrode based on direct electron transfer principle. Open Electrochem J 2:6-10

30. Ogura Y (1951) Studies on the glucose dehydrogenase of Aspergillus oryzae. J Biochem 38(1):75-84

31. Lovallo N, Cox-Foster DL (1999) Alteration in FAD-glucose dehydrogenase activity and hemocyte behavior contribute to initial disruption of Manduca sexta immune response to Cotesia congregata parasitoids. J Insect Physiol 45(12):1037-1048

32. Cavener DR, MacIntyre RJ (1983) Biphasic expression and function of glucose dehydrogenase in Drosophila melanogaster. Proc Natl Acad Sci 80:6286-6288

33. Okuda-Shimazaki J, Kakehi N, Yamazaki T, Tomiyama M, Sode K (2008) Biofuel cell system employing thermostable glucose dehydrogenase. Biotechnol Lett 30(10):1753-1758

34. Omura H, Sanada H, Yada T, Morita T, Kuyama M, Ikeda T, Kano K, Tsujimura S (2009) Coenzyme-binding glucose dehydrogenase. United States Patent 7514250

35. Tsuji Y, Kitabayashi M, Kishimoto T, Nishiya Y (2010) Glucose dehydrogenase from Aspergillus oryzae. US Patent

36. Aiba H, Tsugura-shi J (2007) Novel glucose dehydrogenase. US Patent

37. Zafar MN, Wang X, Ludwig R, Leech D, Gorton L (2012) Electron transfer studies with new FAD-dependent glucose dehydrogenase and osmium polymers of different redox potentials. Anal Chem. doi:10.1021/ac202647z 
38. Sygmund C, Klausberger M, Felice AK, Ludwig R (2011) Reduction of quinones and phenoxy radicals by extracellular glucose dehydrogenase from Glomerella cingulata suggests a role in plant pathogenicity. Microbiology 157:3203-3212

39. Sygmund C, Wührer P, Klausberger M, Pinotsis N, Djinovic K, Gorton L, Haltrich D, Ludwig R (2012) Heterologous overexpression of Glomerella cingulata FAD-dependent glucose dehydrogenase in Escherichia coli and Pichia pastoris. BMC Microb Cell Fact. doi:10.1186/1475-2859-10-106

40. Boland S (2008) Doctoral thesis. National University of Ireland, Galway

41. Appelqvist R, Marko-Varga G, Gorton L, Torstensson A, Johansson G (1985) Enzymatic determination of glucose in a flow system by catalytic oxidation of the nicotinamide coenzyme at a chemically modified electrode. Anal Chim Acta 169:237-247

42. Haghighi B, Gorton L, Ruzgas T, Jönsson L (2003) Characterization of graphite electrodes modified with laccase from Trametes versicolor and their use for bioelectrochemical monitoring of phenolic compounds in flow injection analysis. Anal Chim Acta 487(1):3-14

43. Tasca F, Timur S, Ludwig R, Haltrich D, Volc J, Antiochia R, Gorton L (2007) Amperometric biosensors for detection of sugars based on the electrical wiring of different pyranose oxidases and pyranose dehydrogenases with osmium redox polymer on graphite electrodes. Electroanalysis 19(2-3):294-302

44. Jaegfeldt H, Kuwana T, Johansson G (1983) Electrochemical stability of catechols with a pyrene side chain strongly adsorbed on graphite electrodes for catalytic oxidation of dihydronicotinamide adenine dinucleotide. J Am Chem Soc 105(7):1805-1814

45. Heller A (1992) Electrical connection of enzyme redox centers to electrodes. J Phys Chem 96(9):3579-3587

46. Jenkins PA, Boland S, Kavanagh P, Leech D (2009) Evaluation of performance and stability of biocatalytic redox films constructed with different copper oxygenases and osmium-based redox polymers. Bioelectrochemistry 76(1-2):162-168

47. Boland S, Jenkins P, Kavanagh P, Leech D (2009) Biocatalytic fuel cells: a comparison of surface pre-treatments for anchoring biocatalytic redox films on electrode surfaces. J Electroanal Chem 626 (1-2):111-115
48. Heller A (2006) Electron-conducting redox hydrogels: design, characteristics and synthesis. Curr Opin Chem Biol 10(6):664-672

49. Boland S, Barrière F, Leech D (2008) Designing stable redox-active surfaces: chemical attachment of an osmium complex to glassy carbon electrodes prefunctionalized by electrochemical reduction of an in situ-generated aryldiazonium cation. Langmuir 24(12):63516358

50. Rengaraj S, Kavanagh P, Leech D (2011) A comparison of redox polymer and enzyme co-immobilization on carbon electrodes to provide membrane-less glucose $/ \mathrm{O}_{2}$ enzymatic fuel cells with improved power output and stability. Biosens Bioelectron 30 (1):294-299

51. Cavener DR (1992) GMC oxidoreductases. A newly defined family of homologous proteins with diverse catalytic activities. J Mol Biol 223(3):811-814

52. Coman V, Gustavsson T, Finkelsteinas A, von Wachenfeldt C, Hägerhäll C, Gorton L (2009) Electrical wiring of live, metabolically enhanced Bacillus subtilis cells with flexible osmium-redox polymers. J Am Chem Soc 131(44):1617116176

53. Stoica L (2005) PhD thesis. Dissertation, Lund University, Sweden

54. Aziz AA, Wong FL (2011) Interference elimination of an amperometric glucose biosensor using poly(hydroxyethyl methacrylate) membrane. Eng Life Sci 11(1):20-25

55. Xue H, Shen Z, Li C (2005) Improved selectivity and stability of glucose biosensor based on in situ electropolymerized polyanilinepolyacrylonitrile composite film. Biosens Bioelectron 20(11):2330 2334

56. Nien P-C, Wang J-Y, Chen P-Y, Chen L-C, Ho K-C (2010) Encapsulating benzoquinone and glucose oxidase with a PEDOT film: application to oxygen-independent glucose sensors and glucose $/ \mathrm{O}_{2}$ biofuel cells. Bioresource Technol 101(14):5480-5486

57. Prévoteau A, Courjean O, Mano N (2010) Deglycosylation of glucose oxidase to improve biosensors and biofuel cells. Electrochem Commun 12(2):213-215

58. Courjean O, Flexer V, Prévoteau A, Suraniti E, Mano N (2010) Effect of degree of glycosylation on charge of glucose oxidase and redox hydrogel catalytic efficiency. ChemPhysChem 11(13):2795-2797 